Kto i jak pracuje na uniwersytecie?

W 1991 roku Marc Bousquet, zainfekowany dekonstrukcją absolwent Yale i wzięty copywrighter, rozpoczął swój doktorat poświęcony dziewiętnastowiecznej amerykańskiej kulturze demokracji uczestniczącej na City University of New York. Z pewnością nie spodziewał się wówczas, że jego losy na długo zwiążą się z kulturą pracowników akademickich o niedookreślonym statusie ${ }^{1}$. Gdy po kilku latach pisał wstęp do pierwszego numeru czasopisma "Workplace. A Journal for Academic Labor", przekonywał, że polityczne zaangażowanie na uczelni buduje charakter w czasach gdy znika możliwość prowadzenia kariery i pozostaje jedynie walka, a ponadto stanowi fundament wykonywania dobrej pracy akademickiej ${ }^{2}$. Miał już wówczas za sobą długą działalność w „ruchu pięćdziesięciu kampusów”. Pierwsze próby uzwiązkowienia doktorantów rozpoczęły się w Stanach Zjednoczonych na fali protestów studenckich i działań Ruchu Wolności Słowa pod koniec lat sześćdzie-

1 Więcej na temat barwnego i aktywnego życia politycznego i akademickiego Bousqueta można przeczytać w długim, biograficznym wywiadzie: zob. M. Bousquet i J. Williams, Higher Exploitation, „The Minnesota Review”, Durham 2009.

2 M. Bousquet, Institution as False Promise, „Workplace. A Journal for Academic Labor” 1998, vol. 1, no. 1, s. 8. Czasopismo ukazuje się do dzisiaj, a wszystkie numery dostępne są online na stronie: http://ojs.library.ubc.ca/index.php/ workplace 
siątych ${ }^{3}$. Dopiero jednak w latach dziewięćdziesiątych zaobserwowano ożywienie w tej dziedzinie ${ }^{4}$. Od tego czasu datują się pierwsze rzeczywiste zwycięstwa ruchu, to znaczy pierwsze porozumienia zbiorowe zawiązywane między uniwersytetami a organizacjami doktoranckimi czy uznanie pierwszych organizacji doktoranckich na uczelniach prywatnych.

Wydana w 2008 roku książka How the University Works: Higher Education and the Low-Wage Nation ${ }^{5}$ wyrosła z doświadczenia związkowego i organizacyjnego autora. Wyraża perspektywę prekarnych pracowników uniwersyteckich. Jest to, z jednej strony, teoretyczna próba marksizującego ujęcia stosunków pracy na uniwersytecie, z drugiej zaś etnograficzny opis tego, jak wygląda uniwersytecki system produkcji.

Uniwersytecka prekarna siła robocza posiada uprzywilejowane spojrzenie na zasady funkcjonowania całości systemu pracy akademickiej ${ }^{6}$. Bousquet przyjmuje, że to właśnie wiedza i perspektywa wykształcona w ruchu uzwiązkowienia doktorantów i zatrudnionej tymczasowo kadry uniwersyteckiej może stanowić punkt wyjścia do oporu przeciwko dominującej dziś świadomości menadżerskiej. Wedle jego klasyfikacji pierwsza fala procesu produkcji wiedzy o stosunkach produkcji na uniwersytecie amerykańskim miała miejsce między rokiem 1945 a latami siedemdziesiątymi. Na okres ten przypadała największa aktywność ruchów kadry akademickiej i innych pracowników sektora publicznego, $\mathrm{w}$ tym przede wszystkim nauczycieli. Ich działania były związane z walką o stałe i pewne zatrudnienie [tenure], wolność akademicką oraz demokrację w miejscu pracy wykraczającą dalece poza zhierarchizowane stosunki rządów kolegialnych i profesjonalnych. Na początku lat siedemdziesiątych Komisja Carnegie do spraw szkolnictwa wyższego w jednym ze swoich raportów stwierdzała, że po fali protestów oraz procesów organizacyjnych dokonywanych przez studentów może nadejść fala

3 Pierwszym uniwersytetem, który uznał w 1969 roku związek doktorantów (Teaching Assistants' Association) w Stanach Zjednoczonych był Uniwersytet Wisconsin w Madison. R.A. Rhoads, G. Rhoades, Graduate Employee Unionization as Symbol of and Challenge to the Corporatization of U.S. Research Universities, „The Journal of Higher Education” 2005, vol. 76, no. 3, s. 243-275.

4 W ciągu dziesięciu lat liczba uzwiązkowionych doktorantów w USA zwiększyła się o 175\%. Podczas gdy w roku 1990 było ich 14 060, w 1995 już 19900 , natomiast w 2001 roku ich liczba sięgnęła 38 750. S. Smallwood, Success and new burdles for T.A. unions, „The Chronicle of Higher Education” 2001, A12.

5 M. Bousquet, How the University Works: Higher Education and the Low-Wage Nation, New York 2008.

6 Tamże, s. 92. 
oporu i organizacji pracowniczej na uniwersytetach pod wodzą silnie uzwiązkowionej kadry. To zaś mogło zagrozić tożsamości świeżo nabierających kształtu multiwersytetów ${ }^{7}$ zdecydowanie poważniej niż wyzwania rzucone programom nauczania przez Nową Lewicę pod koniec lat sześćdziesiątych $^{8}$. Clark Kerr w 1972 roku rozważając konsekwencje rewolt studenckich, widział w uzwiązkowionej kadrze przede wszystkim blokadę postępu, największą „konserwatywną” siłę na uniwersytecie,

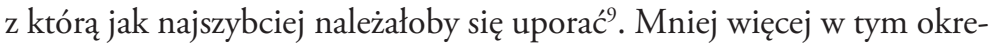
sie w USA rozpoczęła się rewolucja menadżerska ${ }^{10}$ w szkolnictwie wyższym, z omówieniem struktury i konsekwencji której Bousquet zmaga się w całej swojej książce. Związane z nią teorie zarządzania to według niego druga fala procesu tworzenia wiedzy o stosunkach pracy na amerykańskim uniwersytecie. Twierdzi, że była to w dużej mierze odpowiedź na rosnącą w siłę, politycznie zorganizowaną, radykalną kadrę akademicką i studentów.

\section{Linie konfliktu}

Aby uchwycić i opisać typ idealny świadomości menadżerskiej, Bousquet posługuje się m.in. przykładem administracyjnego panelu kontrolnego ${ }^{11}$ z Virtual U, gry stworzonej na zamówienie Sloan Foudnation pod kierownictwem Williama Massy' ego ${ }^{12}$. Podkreśla, że ucieleśniony w tej grze

7 C. Kerr, The Idea of a Multiversity, [w:] The Uses of the University, Cambridge MA-London 2001, s. 1-34.

8 Ciekawe omówienie zarówno osiągnięć ruchów uniwersyteckich w USA z lat sześćdziesiątych, jak również reakcyjnej odpowiedzi na nie czytelniczka znajdzie w dwóch kolejnych rozdziałach najnowszej książki Ellen Schrecker, profesorki Yeshiva University, silnie związanej z AUUP, zob. tejże, The Lost Soul of Higher Education: Corporatization, the Assault on Academic Freedom, and the End of the American University, New York-London 2010, s. 57-122.

9 C. Kerr, Reconsiderations after the Revolts of the 1960's, [w:] The Uses of the University, s. 99.

10 F.E. Rourke, G.E. Brooks, The Managerial Revolution in Higher Education, „Political Science Quarterly” 1967, vol. 82, no. 4, s. 155. Zob. również G. Keller, Academic Strategy: the Management Revolution in American Higher Education, New York 1983.

11 M. Bousquet, Administracyjny panel kontrolny. Tablica rozdzielcza zarządzania: Virtual U Williama Massy'ego, tłum. A. Wojczyńska, [w:] Edu-factory: Samoorganizacja i opór w fabrykach wiedzy, red. J. Sowa, K. Szadkowski, Kraków 2011, s. 80-93.

12 W.F. Massy, Virtual U, 1999, http://www.educause.edu/conference/e99/ proceedings.html. 
model świadomości zakłada, że pracownicy akademiccy są jedynie uciążliwymi zmiennymi na pulpicie kontrolnym, naprzykrzającymi się kadrze kierowniczej tym bardziej, im bezpieczniejsze posiadają miejsca pracy. Choć można rozgrywać różne scenariusze w różnych instytucjach, to jednak w grze dostępna jest tylko jedna perspektywa, spojrzenie władzy. Tylko z perspektywy kierownictwa można objąć całą instytucje, służy do tego wyłącznie jeden wskaźnik - przepływy finansowe - wykaz zysków i strat. Kadra jest tylko zmienną, uwzględnianą realnie o tyle, o ile stwarza problemy. Na szczęście rektor w tym idealnym świecie ma możliwość bardzo łatwego zwalniania tymczasowych pracowników, a dodatkowo jedną z jego prerogatyw jest możliwość dostosowywania poziomów zatrudnienia stałego/czasowego. Bousquet wskazuje na sprzeczności takiego podejścia, przyglądając się jedynemu możliwemu sposobowi rozwiązania scenariusza dotyczącego poprawy warunków kształcenia. Można go zrealizować wyłącznie poprzez zatrudnienie tymczasowej kadry, młodych pracowników czy doktorantów. Chodzi o zmniejszenie kosztów. W ramach takiej menadżerskiej teorii działania decyzje kadry kierowniczej są czynnikami sprawczymi historii danej instytucji. Uzupełnia ją menedżerska teoria wartości, głosząca, że to działania decydentów są odpowiedzialne za akumulację prywatnych i publicznych dóbr na uniwersytecie.

Bousquet stwierdza, że uniwersytet znajdujący się pod dominacją

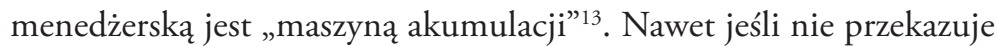
zysków w formie dywidendy udziałowcom - to rozdystrybuuje je w nierówny sposób w obrębie administracji i wpływowej kadry. Jest to akumulacja bez końca, gdyż, jak zaznaczają Harney i Moten, nawet zwiększona efektywność pracy akademickiej w kategoriach ekonomicznych wcale nie zmniejsza ani nie spowalnia zabiegów kierownictwa mających na celu uzyskiwanie większej ilości wartości dodatkowej ${ }^{14}$. Z kogo zatem wyciska się wartość dodatkową na uniwersytecie?

\section{Kto pracuje na uniwersytecie?}

Bousquet podąża za hasłem uzwiązkowionych doktorantów: „Uniwersytet działa, ponieważ pracujemy” [„University Works Because We Do?’], rozbrzmiewającym w latach dziewięćdziesiątych na wielu amerykańskich

13 M. Bousquet, How the University Works..., s. 7.

14 S. Harney, F. Moten, Doing Academic Work, [w:] Chalk Lines: the Politics of Work in the Managed University, red. R. Martin, Durham-London 1998, s. 165. 
kampusach $^{15}$, uznając je za esencję świadomości uczestników trzeciej fali tworzenia wiedzy o uniwersyteckim systemie produkcji. Rozpoznanie produkcyjnego charakteru swoich działań jest pierwszym krokiem do uzyskania politycznego rozpoznania własnego położenia pozwalającego na podjęcie kroków mających na celu regulację warunków ich wykonywania. Tak było w przypadku feministycznych walk o płacę za pracę domową, tak jest w przypadku nieopłacanego lub niskopłatnego kształcenia wykonywanego przez doktorantów. Stwierdzenie „My pracujemy!” negujące ideologię „terminowania”, „studiowania”, staje się punktem wyjścia do negocjowania zarówno swojego statusu prawnego i praw, jak i samych warunków wykonywania pracy ${ }^{16}$. Jednak by dotrzeć do tej konstatacji, wpierw należałoby zadać kilka konkretnych pytań, a mianowicie: kto i w jakich warunkach swoją pracą wprawia w ruch instytucje szkolnictwa wyższego? W jakie stosunki pracy uwikłany jest uniwersytet? Jakie hierarchie zatrudnienia na nim występują? Z czyjej perspektywy definiowane jest to, co jest pracą, a co nie-pracą na uniwersytecie? Do narzucania jakiego rodzaju stosunków na rynku pracy wykorzystywane jest szkolnictwo wyższe? Wszystkie te pytania interesują Bousqueta w równym stopniu, składają się bowiem na tytułowe pytanie jego książki o to, „jak działa/pracuje uniwersytet?”.

Fred Moten i Stefano Harney twierdzą, że należałoby przejść od tożsamościowego pytania o to, kto jest pracownikiem akademickim do zapytywania o to, co to znaczy pracować akademicko ${ }^{17}$. Pozwala to bowiem otworzyć rozważania nad pracą akademicką na wkład, jaki wnoszą w nią studenci. Jest to również przydatna perspektywa, jeśli chcielibyśmy zająć się budowaniem wspólnego frontu pracowników akademickich niższego szczebla i studentów. Wskazuje, że można połączyć się w walce o godne warunki wszystkich „pracujących” na uniwersytecie i poza nim. Podobnie zresztą sądzi Harry Cleaver, który, w być może trochę bardziej zdecydowany sposób, postrzega proces edukacji jako narzucanie pracy studentom, przystosowywanie do przyszłej pracy najemnej poza uczelnią, dyscyplinowanie i ocenianie mające na celu przyzwyczajenie do przyszłych hierarchi w pozaakademickim miejscu pracy $^{18}$. Mogłoby się wydawać, że mamy tu do czynienia z zafiksowaniem

15 M. Dixon, D. Tope, N. Van Dyke, "The University Works Because We Do": on the Determinants of Campus Labor Organizing in the 1990s, „Sociological Perspectives" 2008, vol. 51, no. 2, s. 375-396.

16 M. Bousquet, How the University Works..., s. 50.

17 S. Harney, F. Moten, Doing Academic Work, s. 158.

18 H. Cleaver, Praca $w$ szkole i walka przeciwko pracy $w$ szkole, „Przegląd Anarchistyczny" 2012, nr 13.

\section{Rozpoznanie}

produkcyjnego

charakteru swoich

działań jest pierwszym

krokiem do uzyskania

politycznego

rozpoznania własnego

położenia

pozwalającego na

podjęcie kroków

mających na celu

regulację warunków ich wykonywania. Tak było

w przypadku

feministycznych walk

o płacę za pracę

domową, tak jest

w przypadku

nieopłacanego lub

niskopłatnego

kształcenia

wykonywanego przez

doktorantów 
na pracy i produkcji. Spychane na margines są rozważania na temat samej treści i procesu kształcenia czy badania, warunków produkcji, akumulacji i dystrybucji wiedzy. Perspektywa przyjmowana przez Bosuqueta i innych marksistów badających uniwersytet nie jest po prostu kolejnym spłaszczającym, ekonomistycznym podejściem do zagadnień nauki i edukacji. Próbuje raczej odpowiedzieć na przesunięcie zainteresowań i akcentów w działalności samego uniwersytetu.

\section{Studenci są już pracownikami}

Zarówno w Stanach Zjednoczonych, jak i w Europie uniwersytety w coraz większym stopniu zachęcane są do wchodzenia w partnerstwa ze swoim otoczeniem biznesowym i społecznym. Tego typu działania określa się często mianem „trzeciej misji” uniwersytetu ${ }^{19}$. Uniwersytety, czego chyba nikomu w Polsce nie trzeba przypominać, przymuszane są również do wychodzenia naprzeciw potrzebom pracodawców. Bousquet, inaczej niż Harney i Moten czy Cleaver, dość dosłownie rozumie to, że bycie studentem oznacza zawsze już pewien sposób bycia pracownikiem $^{20}$. Rozdział czwarty How the University Works ${ }^{21}$ zawiera doskonałe studium przypadku tego, o jaki typ pracy i partnerstwa z otoczeniem społeczno-gospodarczym mogłoby tutaj chodzić. Opisana tam współpraca zawiązana między kurierską firmą UPS, miastem Louisville a University of Lousiville o nazwie Metropolitan College nie zajmowała się w żadnym wypadku procesem wykwalifikowanego kształcenia. Jej jedyną funkcją było wabienie studentów do podpisywania umów na tanią, elastyczną pracę w UPS,w zamian za obniżkę czesnego w partnerskich instytucjach szkolnictwa wyższego. Z punktu widzenia stron zawiązujących partnerstwo wszyscy byli zwycięzcami: miasto obniżało wskaźniki bezrobocia wśród młodych, jednocześnie podnosząc poziom skolaryzacji na poziomie wyższym; uniwersytet otrzymywał stały dopływ klientów regularnie płacących czesne; natomiast UPS było w stanie zapewnić sobie komplet pracowników na najmniej korzystnych zmianach. Pomysł partnerstwa zrodził się w UPS jako strategia w odpowiedzi na strajki i niesubordynację pracowników tymczasowych. W 2003 roku

19 Zob. P. Laredo, Revisiting the Third Mission of Universities: Toward a Renewed Categorization of University Activities?, „Higher Education Policy” 2007, vol. 20, no. 4, s. 441-456.

20 M. Bousquet, How the University Works..., s. 46.

21 Tamże, s. 125-156. 
studenci różnego typu stanowili ponad połowę spośród 130000 pracowników tymczasowych w UPS - najczęściej byli lokowani na najmniej korzystnych zmianach. Największe obniżki czesnego obiecywane były studentom, którzy zgodzili się na najgorsze warunki (nocne zmiany po północy w każdym dniu tygodnia szkoły). Wszystkie korzyści dla studentów rekrutowanych przez Metropolitan College uzależnione były od tego, czy pojawią się każdej nocy roku szkolnego i będą wykonywać fizycznie wyczerpującą pracę tak długo, jak będą potrzebni. Studentów trzymało się na tych nocnych zmianach przez 3-4 godziny, płacąc po 8,5-9,5\$ za godzinę - co przy konieczności pojawienia się na 5 nocach w tygodniu daje około 100-120\$ na tydzień. Większość studentów, by się utrzymać, musiała w konsekwencji posiadać dodatkową pracę. Oczywiście cała ta sytuacja wpływała negatywnie na ich wyniki w nauce. Studenci zakontraktowani w Metropolitan College raczej nie utrzymywali się długo na uczelni. Jak podaje Bousquet, w trakcie wieloletniego trwania programu, tylko w ramach partnerstwa z University Louisville, spośród 10000 studentów jedynie 300 osób otrzymało dyplomy. Z tym niskim poziomem powodzenia wiązała się utrata zniżek w razie ponownego podjęcia studiów, jak również dotychczasowych wpłat czesnego dokonanych przez studentów.

Choć mocno zakorzeniony w amerykańskiej rzeczywistości powszechnego czesnego, przykład Bousqueta pozwala dotknąć szerszego fenomenu. Okres studiów dla wielu studentów coraz częściej staje się okresem wytężonej pracy - niestety w coraz większym stopniu odbywającej się poza murami uczelni czy biblioteki. Studenci stają się przede wszystkim tanią siłą roboczą 22 już w trakcie studiów, a nie siłą roboczą w procesie kształcenia $^{23}$. W półperyferyjnych gospodarkach, takich jak Polska, niezdolnych do absorbcji wysoce wykształconych pracowników, to sektor usług i elastyczna tania praca $w$ ich ramach, a nie innowacyjne przemysły kreatywne mówią prawdę o całej „gospodarce opartej na wiedzy”.

Kto jednak ponosi koszty tych niskich płac? Odpowiedź, którą sugeruje Bosuquet tylko z pozoru wydaje się uproszczona: wszyscy tylko nie pracodawcy. System taniej i elastycznej pracy studentów może istnieć, gdy subsydiuje go państwo/miasto/samorząd z publicznych pieniędzy, oraz gdy równolegle wspiera się na sieciach afektywnych samych stu-

22 Tamże, s. 156.

$23 \mathrm{Na}$ ten fakt wskazują również przedstawiciele kolektywu Edu-factory i jego czołowy przedstawiciel, Gigi Roggero, zob. tegoż, The Production of Living Knowledge: the Crisis of the University and the Transformation of Labor in Europe and North America, tłum. E. Brophy, Philadelphia 2011.
Okres studiów dla wielu studentów coraz częściej staje się okresem wytężonej pracy - niestety w coraz większym stopniu odbywającej się poza murami uczelni czy biblioteki. Studenci stają się przede wszystkim tanią siłą roboczą już w trakcie studiów, a nie siłą roboczą w procesie kształcenia 
dentów - gdy wspierają ich rodziny i grono przyjaciół. Wytwarza on obszerną sieć zależności - firmy zatrudniające studentów, w omawianym wypadku UPS, mogą utrzymywać ceny swoich usług na odpowiednio niskim poziomie przy zagwarantowaniu sobie stabilnych zysków, tym samym przyzwyczajając do niskich kosztów swoich usług rzesze odbiorców. Pracujący studenci i przyzwyczajeni do prekarności absolwenci humanistycznych kierunków stanowią element podstawy, na której wspierają się oparte na hiperwyzysku gospodarki usługowe.

Przywoływani przez Bousqueta kierownicy UPS mówili otwarcie, że niemożliwe byłoby rozszerzanie firmy i hubów transportowych bez publicznego wsparcia i taniej pracy studentów. W Polsce pracodawcy studentów do 26 roku życia zatrudnionych na umowach-zleceniach zwolnieni są z obowiązku odprowadzania składki na ubezpieczenia społeczne (ZUS). Polski system szkolnictwa wyższego odgrywa tym samym istotną i strukturalną rolę w przystosowywywaniu studentów do prekarności, umożliwia ich tańsze zatrudnianie na gorszych warunkach. Wikła się w mechanizm pozwalający na obniżanie kosztów siły roboczej, nie przynosząc ostatecznie żadnych korzyści samym studentom, dostarczając jedynie złudzenie „praktyki zawodowej”.

\section{Produkty uboczne systemu}

Teoretyczki takie, jak chociażby Saskia Sassen, od lat piszące o zmieniających się geografiach centralności i marginalności ${ }^{24}$ twierdzą, że kapitał w ramach nowej gospodarki przenosi produkcję nie tylko tam, gdzie praca jest najtańsza, ale tam, gdzie najłatwiej ją kontrolować, tam gdzie robotnicy są możliwie niezorganizowani i bezsilni ${ }^{25}$. Tworzone są obszary marginalności w kapitalistycznym centrum. W ten sposób nawet w ramach wysoce rozwiniętych gospodarek istnieją zasoby siły roboczej łatwo dającej się dyscyplinować, funkcjonującej w ramach nieformalnych stosunków zatrudnienia. Bousquet podejmuje ten argument i wskazuje, że również wewnątrz najbardziej rozwiniętych systemów szkolnictwa wyższego funkcjonują i ze strukturalnych powodów muszą funkcjonować dla podtrzymywania efektywności systemu, nieformalne obszary pracy akademickiej; sfery, w których działają pracownicy o nieokreślonym

24 S. Sassen, Globalizacja: Eseje o nowej mobilności ludzi i pieniędzy, tłum. J. Tagnerowicz, Kraków 2007.

25 Tejże, The Mobility of Labor and Capital: a Study in International Investment and Labor Flow, Cambridge 1990, s. 39. 
statusie: doktoranci, pracownicy akademiccy zatrudnieni na umowy-zlecenia, badacze na post-docach itp., to znaczy tacy, których w danej instytucji łatwo zaprząc do pracy, łatwo ich zwolnić i usunąć, a im samym stosunkowo trudno się zorganizować i uzyskiwać należne prawa.

Doktoranci przez jakiś czas wykonują pracę akademicką na rzecz uniwersytetów, w których piszą swoje doktoraty. W Stanach Zjednoczonych ten okres trwa zdecydowanie dłużej, około 7-8 lat, niż w Polsce czy przeciętnie w Europie, gdzie średnio trwa około 4 lat. Bousquet uważa, że w momencie kiedy kończą swoją pracę nad doktoratem, stają się „odpadami systemu edukacji doktoranckiej” ${ }^{26}$. W wielu dziedzinach, szczególnie humanistycznych - koniec studiów doktoranckich oznacza dla nich koniec kariery akademickiej. Według niego większość instytucji w USA, w ramach których działają programy doktoranckie, przyjmuje studentów, aby odpowiadać na konkretne zapotrzebowanie na pracę, np. dydaktyczną ${ }^{27}$. Jest ich zawsze „w sam raz”, aby zaspokoić „na czas” zapotrzebowanie na pracę danych instytucji ${ }^{28}$.

Polskie uczelnie przez dwadzieścia lat po transformacji zachęcane były do podejmowania działań przedsiębiorczych w ramach usług dydaktycznych, konkurując tym samym o studentów i wpływy z czesnego z wyłaniającym się w tym okresie sektorem prywatnym. Na wielu uczelniach rozwinęły się odpłatne studia zaoczne (wpierw określane mianem wieczorowych), a wpływy z dydaktyki zaczęły stanowić istotny element budżetów polskich publicznych uczelni wyższych ${ }^{29}$. Tania (czasami bezpłatna) i niepewna siła robocza doktorantów jest zmuszona wykonywać na rzecz uniwersytetu do 90 godzin „praktyk” dydaktycznych. Często pracuje za najniższe stawki w czasie weekendów ze studentami zaocznymi. Stanowiła i nadal stanowi element krajobrazu na polskich uczelniach publicznych i pozwalała uczynić proceder odpłatnego kształcenia bardziej zyskownym. Niestety skala i zakres tego zjawiska jest czymś, co ciągle pozostaje w Polsce do zbadania.

26 M. Bousquet, The Waste Product of Graduate Education: Toward a Dictatorship of the Flexible, "Social Text” 2002, vol. 20, no. 1, s. 81-104.

27 M. Bousquet, How the University Works..., s. 20.

28 Tamże, s. 188.

29 Dla uczelni publicznych w 2008 roku wskaźnik przychodów z opłat z czesnego wynosił ok. $22 \%$ sumy wszystkich przychodów - jak na kraj, w którym nie wprowadzono do tej pory powszechnego czesnego w sektorze publicznym to bardzo wysoki wynik. Zob. B. Jongbloed, H. de Boer, Higher Education Funding Reforms in Europe and the 2006 Modernisation Agenda, [w:] The Modernisation of European Universities: Corss-National Academic Perspectives, red. M. Kwiek, A. Kurkiewicz, Peter Lang, Frankfurt am Main 2012, s. 134. 
Studenci i doktoranci to zatem ktoś, kto może zostać zaprzęgnięty do pracy, ale najczęściej nie posiada należnych praw. Doktorantów można postrzegać właśnie przez pryzmat kategorii „nie-pracowników”. Zrozumienie, że doktoranci „pracują”, prowadzi Bousqueta do wysunięcia kilku twierdzeń ${ }^{30}$. Przede wszystkim uważa, że nie „nadprodukujemy doktoratów”, produkujemy za mało stanwisk przyszłej pracy dla świeżo obronionych doktorów. Jest to dość istotne przesunięcie perspektywy i można je zastosować również do analizy sytuacji studentów na rynku pracy. Tajemnicą poliszynela wydaje się to, że polski rynek pracy nie generuje zapotrzebowania na wysokowyspecjalizowanych pracowników; najczęściej poszukiwanymi pracownikami są ludzie o niskich kwalifikacjach $^{31}$. Pojęcie nadprodukcji odnosi się do kwestii zysków, a nie potrzeb ludzi; kapitalizm, również ten akademicki, „nadprodukuje” w momencie kiedy coś przynosi za małe zyski. Ponadto, jak twierdzi Bousquet, umożliwione przez zatrudnienie taniej i niepewnej siły roboczej tanie kształcenie - podstawa umasowienia szkolnictwa wyższego w Polsce - nie jest przestępstwem pozbawionym ofiar. Dlaczego ci, którzy w USA płacą nieraz 50000 za rok studiów, mają się kształcić pod okiem ludzi posiadających często mniej niż roczne doświadczenie pedagogiczne? Dodatkowo niskie koszty i dezorganizacja elastycznych pracowników wspierają przyspieszenie $^{32}$ i wzmacniają wyzysk w całym systemie pracy akademickiej - w końcu jeśli pracownicy na stałych posadach nie będą dostosowywać się do rosnących wymagań, chętnie zastąpią ich aktualni doktoranci czy pracownicy tymczasowi.

\section{Przeciwko wyzyskowi żywej pracy}

Jaki zatem pożytek w dzisiejszej Polsce może przynieść lektura dość szczegółowej i gęstej narracji na temat pracy akademickiej, jej organizacji, relacji z menadżmentem? Czy chcemy tego, czy nie, polskim uniwersytetom jeszcze wciąż daleko do realiów opisywanych przez Bousqueta - do sytuacji bardziej klarownego antagonizmu między pracownikami a wyłaniającym się centrum kierowniczym. Jest tak choćby przez wciąż względnie niski poziom autonomii polskich uniwersytetów publicznych w kwe-

30 M. Bousquet, How the University Works..., s. 41-44.

31 Wystarczy przyjrzeć się publikowanym corocznie przez GUS wykazom zawodów deficytowych i nadwyżkowych.

32 Tamże, s. 42. 
stiach ustalania warunków pracy swoich pracowników ${ }^{33}$. Dodatkowo, na peryferyjnym uniwersytecie linie konfliktu wokół narzucania pracy, wyciskania wartości dodakowej czy mechanizmów przemocy kierowniczej lub pozbawiania praw pracowników o słabo zdefiniowanym statusie łatwo przykrywane są przez anachroniczne konflikty wokół apolityczności/upolityczniania uniwersytetu.

Problemy z analizą Bousqueta wykraczają z pewnością daleko poza jej mocno osadzony w konteście amerykańskim charakter. Kompletnie pomija on badawczy wymiar działalności uniwersytetów i ich pracowników. Nie przejmuje się szczególnie stosunkami własności w instytucjach szkolnictwa wyższego, nie interesuje go przemoc mechanizmów patentowych ani spółki odpryskowe wyprowadzające zyski z finansowanych publicznie badań poza uniwersytet, czy też wielki przemysł wydawnictw akademickich. W How the University Works pokutuje również wielokrotnie zwalczane przez Andrzeja W. Nowaka w szeregach krytycznych autorów i autorek piszących o uniwersytecie ${ }^{34}$ zawężenie perspektywy wyłącznie do nauk humanistycznych i społecznych. Bousquet otwarcie przyznaje, że skupia się jedynie na pracy na wydziałach humanistycznych czy społecznych - generalnie tych zorientowanych na odpłatne kształcenie. Ogromną wartością książki Bousqueta jest natomiast zerwanie z konserwatywnym poglądem wielu krytyków „korporatyzacji” uniwersytetu głoszącym, że utowarowienie edukacji, komercjalizacja badań i wypracowanie zachowań biznesowych przez uniwersytety zostało narzucone z zewnątrz ${ }^{35}$. Proces utowarowienia edukacji oznacza dla Bousqueta przede wszystkim podnoszenie poziomu wyzysku żywej pracy ${ }^{36}$, towarzyszy mu natomiast wyodrębnianie się często przeciwstawnych sobie klas pracowników: administracji, „szefów na stałych posadach oraz

33 Choć i w tym obszarze możemy się zapewne niedługo spodziewać zmian. Wskazują na to choćby założenia nowego projektu zmian ustawy o szkolnictwie wyższym. Zob. MNiSW, Projekt zatożeń projektu ustawy o zmianie ustawy - Prawo o szkolnictwie wyższym oraz niektórych innych ustaw, 2013.

34 Zob. choćby jego tekst z tego numeru - A. W. Nowak, Demokratyzowanie czy neoluddyzm - reforma uniwersytetu wobec wyzwań technonauki, „Praktyka Teoretyczna" 1(7)/2013.

35 Czy to przez państwo, czy przez biznes - przykładem takiej krytyki jest choćby L.C. Soley, Leasing the Ivory Tower: the Corporate Takeover of Academia, Boston 1995. Bousquet, podobnie jak Sheila Slaughter, Garry Rhoades czy Larry Leslie, twierdzi, że tego typu zmiany nie byłyby nigdy możliwe bez aktywnego udziału kadry akademickiej i wypracowania specyficznej kultury przedsiębiorczości na uniwerystetach. Zob. np. G. Rhoades, S. Slaughter, Academic Capitalism and the New Economy: Markets, State, and Higher Education, Baltimore 2004.

36 M. Bousquet, How the University Works..., s. 85. 
rozporządzalnych nauczycieli”37. Jest to jedno z podstawowych założeń przyjmowanych przez Bousqueta w How the University Works, czyniące ostatecznie tę perspektywę wartą podjęcia i przyswojenia na polskim gruncie. Mimo że warunki opisywane przez niego nie zostaną tu pewnie nigdy w pełni odwzorowane.

Recenzja ksiąziki M. Bousquet, How the University Works: Higher Education and the Low-Wage Nation, New York and London 2008.

37 Tenured Bosses and Disposable Teachers: Writing Instruction in the Managed University, red. M. Bousquet, T. Scott, L. Parascondola, Carbondale 2004. 
KRYSTIAN SZADKOWSKI - doktorant w Instytucie Filozofii UAM, badacz w Instytucie Badawczym Education International w Brukseli. Zajmuje się problematyką szkolnictwa wyższego i kapitalizmu kognitywnego oraz ich wzajemnych relacji.

Dane adresowe:

Instytut Filozofii UAM

ul. Szamarzewskiego 89a

60-568 Poznań

e-mail: krystian.szadkowski@ei-ie.org

\section{Cytowanie:}

K. Szadkowski, Kto i jak pracuje na uniwersytecie, „Praktyka Teoretyczna” nr 1(7)/2013, http://www.praktykateoretyczna.pl/PT_nr7_2013_ NOU/19.Szadkowski.pdf (dostęp dzień miesiąc rok)

Author: Krystian Szadkowski

Title: Who and how works at the university? 